\title{
Closed fishing season law a positive instrument to minimize illegal fishing of the remaining stock of Arapaima sp. In the Brazilian Amazon
}

The increasing demand for fish on a global level has caused an intensification of fishing and, as a consequence, overfishing of fish stock. The pirarucu (Arapaima sp.) is no exception since it is a highly appreciated fish species in the Amazon region, and the growth in fishing activities of this species was responsible for its inclusion in the International Union for Conservation of Nature's red list of Threatened species (IUNC). The current study assessed illegal fishing of pirarucu in the Brazilian Amazon, for the periods preceding and following the implementation of the Closed Fishing Season Law (CFSL), and was carried out using the analysis of data issued by the Brazilian Institute of the Environment and Renewable Natural Resources (IBAMA) Agency for the Brazilian Amazon, from January 1992 to December 2017. A total of 1,829 metric tons of pirarucu were confiscated, and of this amount, $78.13 \%$ corresponded to fiscalization which occurred in the basins of the Solimões and Negro rivers. The mean rates in the 26 years of confiscation of illegally fished pirarucu proved that before the implantation of the CFSL, the illegal fishing of this specie was intense, whereas after the implementation of this law, there was a significant reduction in the number of confiscations. The implementation of the CFSL combined with other restrictive procedures (fishing agreements and inspections) regarding pirarucu fishing has inhibited the illegal fishing of the species. However, in order to maintain this resource, government fishing management policies need to be aware of the need for the preservation of natural renewable resources (fish and their habitats) and the interaction between them, while also considering social and economic development in the region.

Keywords: Pirarucu; Fisheries; Fishery resources.

\section{Lei do defeso como um instrumento positivo para minimizar a pesca ilegal dos estoques remanescentes de Arapaima sp. na Bacia \\ Amazônica}

\begin{abstract}
A crescente procura de peixe a nível mundial tem provocado uma intensificação da pesca e, consequentemente, uma sobrepesca das unidades populacionais. 0 pirarucu (Arapaima sp.) não é exceção, uma vez que é uma espécie de peixe altamente apreciada na região Amazônica, e o crescimento das atividades de pesca desta espécie foi responsável por sua inclusão na União Internacional para a conservação da lista vermelha da União Internacional para a Conservação da Natureza e dos Recursos Naturais (IUCN). O presente estudo avaliou a pesca ilegal de pirarucu na bacia amazônica, nos períodos anteriores e posteriores à implementação da Lei do Defeso (LD), e foi realizado com base na análise de dados emitidos pela Agência Brasileira do Meio Ambiente e Recursos Naturais Renováveis (IBAMA) para o estado Amazônico, de janeiro de 1992 a dezembro de 2017. Um total de 1,829 toneladas métricas de pirarucu foram confiscadas, e desta quantidade, $78.13 \%$ corresponderam à fiscalização que ocorreu nas bacias dos rios Solimões e Negro. As taxas médias nos 26 anos de confisco de pirarucu pescado ilegalmente provaram que, antes da implantação da LD, a pesca ilegal desta espécie era intensa, ao passo que, após a implementação desta lei, houve uma redução significativa no número de confiscos. A aplicação da LD combinada com outros procedimentos restritivos (acordos de pesca e inspeções) relativos à pesca de pirarucu impediu a pesca ilegal da espécie. No entanto, para manter este recurso, as políticas governamentais de gestão das pescas precisam estar conscientes da necessidade de preservação dos recursos naturais renováveis (peixes e seus habitats) e da interação entre eles, considerando também o desenvolvimento social e econômico na região.
\end{abstract}

Palavras-chave: Pirarucu; Pescaria; Recursos Pesqueiros.

Topic: Desenvolvimento, Sustentabilidade e Meio Ambiente

Reviewed anonymously in the process of blind peer
Received: 01/01/2021

Approved: 28/01/2021
Helen Cristina Parazzi de Freitas (iD)

Universidade Federal de Rondônia, Brasil

http://lattes.cnpq.br/35774448319227554

http://orcid.org/0000-0003-1127-2477

hcparazzi@gmail.com

Raniere Garcez Costa Sousa (it)

Universidade Federal de Rondônia, Brasil

http://lattes.cnpq.br/6126537331153727

http://orcid.org/0000-0002-5620-389X

ranieregarcez@unir.b
6

DOI: 10.6008/CBPC2179-6858.2021.001.0039
Referencing this:

FREITAS, H. C. P.; SOUSA, R. G. C.. Closed fishing season law a positive instrument to minimize illegal fishing of the remaining stock of Arapaima sp. In the Brazilian Amazon. Revista Ibero Americana de Ciências Ambientais, v.12, n.1, p.484-494, 2021. DOI: http://doi.org/10.6008/CBPC2179-6858.2021.001.0039 


\section{INTRODUCTION}

The Amazon basin is composed of a large set of river channels and incorporates $20 \%$ of the entire planet's fresh water (SANTOS et al., 2005). This aquatic environment encompasses enormous biodiversity and there are estimated to be between 1.500 to 6.000 fish species alone (ISAAC et al., 2012; LOPES et al., 2018). Due to its abundance of food, this aquatic environment is used as a shelter and nursery for ichthyofauna (SOUSA et al., 2008). This has resulted is a high availability of fishery resources that has made fishing the main income generating activity in the local economy (CORRÊA et al., 2014).

Some studies have shown that fishing activity in the Amazon region is considered not only small scale, but also has a high degree of efficiency (CAVOLE et al., 2015). This claim arises from the fact that fishers understand the behavior of the aquatic environment (flood pulse) and the interaction between it and the fish (GARCEZ et al., 2017), since the fishers have acquired traditional knowledge over the years, which is then transmitted from generation to generation among the resource users (DORIA et al., 2008).

The greatest focus in fisheries is on the tagged fish species with higher commercial values (CORRÊA et al., 2014; CAVOLE et al., 2015), such as tiger sorubim (Pseudoplatystoma tigrinum) (RUFFINO et al., 1999), pescada Plagioscion spp.), Peacock Bass (Cichla spp.) (DORIA et al., 2008), tambaqui (Colossoma macropomum) as reported by Sousa et al. (2017), and pirarucu (Arapaima gigas, Schinz 1822) which is mentioned in studies by Arantes et al. (2010) and Cavole et al. (2015). Although there are several studies that point to the efficiency of Amazonian fishing, this statement is not absolute, given the fact that some are threatened species, as is the case of pirarucu, which has been included on a red list of endangered species by the International Union for Conservation of Nature - IUCN (GÄRDENFORS et al., 1996).

The pirarucu is a species that is native to the Amazon region (MATEUS et al., 2017). It is notable for being large (BARD et al., 1986) and is found in countries such as Peru, Bolivia, Colombia, Ecuador, and Guiana, living in rivers, lakes and other fresh water environments where temperatures range from $24^{\circ}$ to $37^{\circ} \mathrm{C}$. It is not usually found in places with strong currents and/or in waters with sediments (BARD et al., 1986). It is an opportunist omnivore fish that can eat fruits and even small animals such as waterfowl. It is also sedentary and shows rapid growth (WWF, 2011). Adult individuals reach around three meters in length and 200 kilos in weight (VIANA, 2010).

The pirarucu's meat, extracted in fisheries in the form of butterfly fillet, is considered a high quality meat (PEDROZA FILHO et al., 2016), devoid of bones, it has a high nutritional level. Its meat exceeds the pilchard and salmon meat in protein values (LIMA et al., 2012) and is highly appreciated by the consumer (MURRIETA, 2001; SANTOS et al., 2015). Also, its skin can be used in the manufacturing of shoes, bags and clothing, and its scales and tongue are used in the manufacturing of utensils and ornaments, which adds socioeconomic and cultural value to this species that is endemic to the Amazon region (WWF, 2011).

According to different environmental conditions, the pirarucu develops ways to ensure its survival, such as reproduction and eating strategies, lateral and longitudinal migrations, area occupation patterns, and even the avoidance of fishing areas (WWF, 2011). This animal presents a particularity in its respiratory 
system, in which it uses two strategies: the gills and the modified swimming bladder. The latter is specialized and functions as a lung for breathing. Thus, the pirarucu needs to come up to water's surface at regular intervals to take in air (ARANTES et al., 2006; ARANTES et al., 2010). However, in doing so, this fish species become vulnerable to fisher's actions (DIAS et al., 2013).

In order to keep fish stocks at sustainable levels, the Closed Fishing Season Law - CFSL, which was introduced in 2002, (Decree $n^{\circ} .142 / 2002$ ) establishes general and specific regulations regarding the natural reproductive period of fish. Known as the Closed Fishing Season, the spawning season, and also locally known as "piracema", it is essential in maintaining fish populations, especially the overexploited species, such as the pirarucu (GARCEZ et al., 2017).

In the light of the above, the aim of this study was to verify whether there was substantial difference in the total of confiscation of Arapaima sp. after the Closed Season Law entered into force. For this purpose, a database provided by IBAMA, which comprised the confiscations of illegally fished pirarucu over a period of 26 years, between 1992 and 2017, was accessed and analyzed. The pattern of notifications for the illegal fishing violations of the pirarucu was correlated with the amount of confiscations (in metric tons), and a comparison was made of the data for fishery production preceding and following the CFSL.

\section{MATERIALS AND METHODS}

\section{Study area}

The information for this research originated from the analysis and observation of the registrations of violations regarding illegal pirarucu fishing, which occurred in the following river basins: Negro, Amazon, Solimões, Japurá, Juruá, Purus, Uatumã, Javari, Ipixuna, Jutaí, Madeira, Nhamundá and Paraná Urariá. which, since they are the principal rivers of the state, were chosen as the study area (Figure 1).
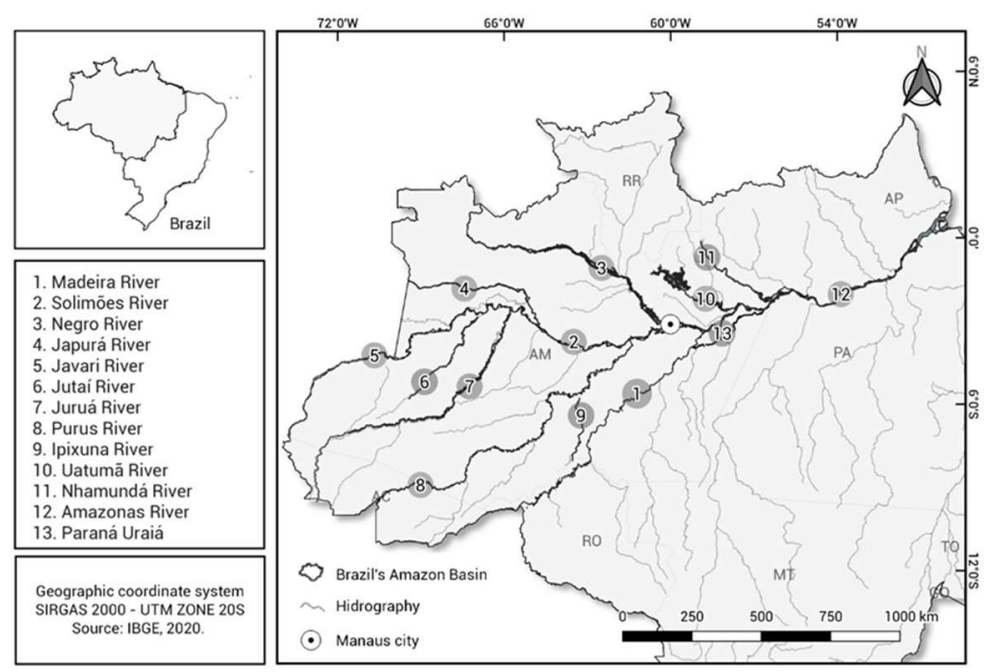

Figure 1: Location of the rivers in the Amazon basin where occurrences of illegal fisheries and successive confiscations of Arapaima sp. have been registered between the years of 1992 and 2017 . Madeira River $\left(6^{\circ} 53^{\prime} 49^{\prime \prime} \mathrm{S} 62^{\circ} 06^{\prime} 23^{\prime \prime} \mathrm{W}\right)$, Ipixuna River ( $\left.7^{\circ} 25^{\prime} 48^{\prime \prime} \mathrm{S} 63^{\circ} 21^{\prime} 23^{\prime \prime} \mathrm{W}\right)$, Purus River (6 $\left.6^{\circ} 48^{\prime} 19^{\prime \prime} \mathrm{S} 66^{\circ} 07^{\prime} 43^{\prime \prime} \mathrm{W}\right)$, Juruá River $\left(6^{\circ} 15^{\prime} 10^{\prime \prime} \mathrm{S} 69^{\circ} 19^{\prime} 04^{\prime \prime} \mathrm{W}\right)$, Javari River $\left(6^{\circ} 15^{\prime} 10^{\prime \prime} \mathrm{S} 69^{\circ} 19^{\prime} 04^{\prime \prime} \mathrm{W}\right)$, Jutaí River ( $\left.4^{\circ} 36^{\prime} 43^{\prime \prime} \mathrm{S} 68^{\circ} 38^{\prime} 36^{\prime \prime} \mathrm{W}\right)$, Japurá River ( $\left.2^{\circ} 19^{\prime} 55^{\prime \prime} \mathrm{S} 67^{\circ} 05^{\prime} 50^{\prime \prime} \mathrm{W}\right)$, Solimões River ( $3^{\circ} 23^{\prime} 02^{\prime \prime} \mathrm{S}$

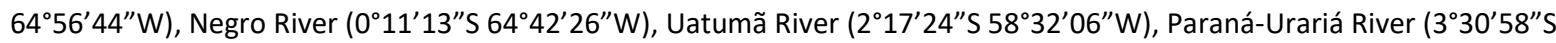
$\left.58^{\circ} 22^{\prime} 26^{\prime \prime} \mathrm{W}\right)$, Amazon River ( $\left.1^{\circ} 38^{\prime} 38^{\prime \prime} \mathrm{S} 61^{\circ} 39^{\prime} 35^{\prime \prime} \mathrm{W}\right)$ and Nhamundá River ( $\left.1^{\circ} 08^{\prime} 35^{\prime \prime} \mathrm{S} 57^{\circ} 39^{\prime} 05^{\prime \prime} \mathrm{W}\right)$. 


\section{Data Collection}

The reference database with the details of confiscations of pirarucu used in this study was provided by the Brazilian Institute for the Environment and Renewable Natural Resources (IBAMA), whose headquarters are located in Manaus, the capital of the Amazonas State. The analysis of confiscations data was carried out on records from the inspection reports and violation notifications which occurred between the years of 1992 and 2017 (authorization for access was registered under the protocol number 02005.103474/2017-44). Also, the dataset related to the measurements of the water level of the Amazon River were obtained from the National Water Agency (ANA) and were be used as the basis of the seasonal hydrological variation applied in this study.

\section{Data Analysis and Organization}

The data obtained from the confiscations of Arapaima sp. in the Brazilian Amazon were entered into electronic spreadsheets, and also consisted of information regarding the names of the rivers, months of the illegal fisheries, years and total of confiscations (in metric tons) where illegal fishing activities took place. The data were first submitted to a descriptive analysis, to verify the mean values and standard deviations, followed by the Pearson test, where the linearity between the total of annual confiscations (in metric tons) and the periods which preceded and followed the implementation of the CFSL were verified. Subsequently, the data on confiscations were grouped by month and by year, and submitted to homogeneity and normality tests, which enabled the possibility of non-parametric analyses in this study.

The Kruskal-Wallis ANOVA test was used to compare the total mean values of the confiscations tons (dependent variable) grouped by months (independent variable). Besides this, the Kolmogov-Smirnov test was used to verify differences among the total monthly means of confiscations (tons, dependent variable) grouped in the periods which preceded and followed the implementation of the CFSL. The water levels of the Amazon River (since it is the main river in the Amazon basin) were used as the central record for the definition of seasons (rising water, flood, receding water, and drought seasons).

\section{RESULTS AND DISCUSSION}

Over 26 years (from January $1^{\text {st }}, 1992$ to December $31^{\text {st }}, 2017$ ), a total of $1,828.67$ tons of Arapaima sp. were confiscated in the Brazilian Amazon, of this total, 1,234.22 tons were computed in the period prior to the CFSL and 594.46 tons in the subsequent period, which implied in a reduction of $67.49 \%$ in the total number of confiscations for the latter period. The main confiscation records of pirarucu fishing occurred in the Solimões River (872.84 tons) and Negro River (555.87 tons), and together accounted for $78.13 \%$ of these occurrences (Figure 2).

When submitted to the Pearson test, the values of total annual rates of confiscation for Arapaima sp. showed two different scenarios: i) Prior to the implementation of the CFSL, the confiscation rates had a strong, positive, and linear relation with the following values for $r^{2}=0.693 ; r=0.833$ and $p=0.003$ related to 
the regression equation with $y=-86516.0006+43.3956^{*} x$, and ii) After the implementation of CFSL, the confiscation rates showed a moderate and negative relation with $r^{2}=0.518 ; r=-0.720$ and $p=0.002$; and regression equation of $y=18812.619-9.3398^{*} x$ (Figure 3 ).

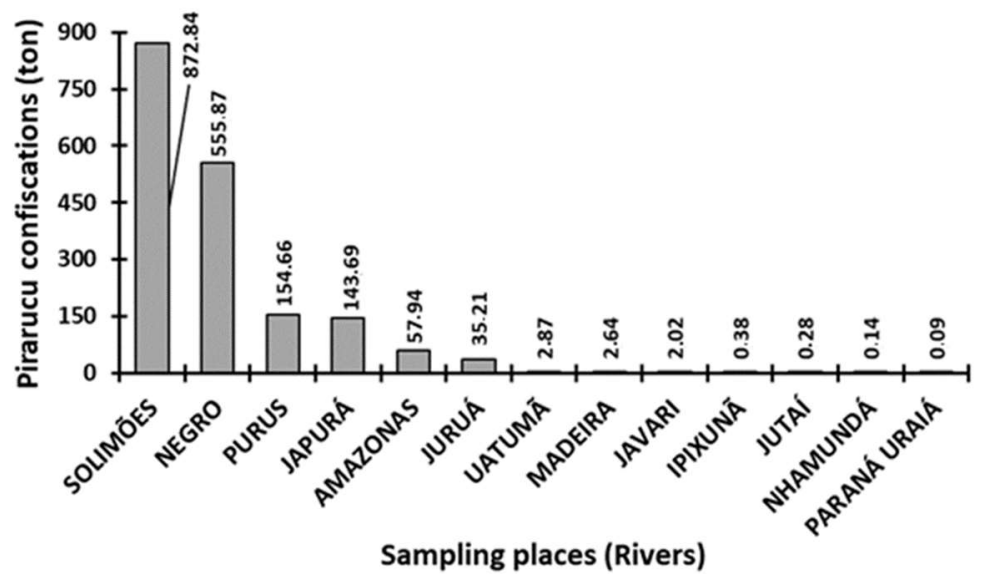

Figure 2: Absolute frequency of total number of confiscations of Arapaima sp. in metric tons from the violation notifications for the Brazilian Amazon (from 1992 to 2017).

Kolmogorov-Smirnov's test showed a significant difference $(p<0.05)$ for the means of the total number of confiscations (in tons) in the period preeceding 2002 (9.35 \pm 19.70 tons) and the period (3.30 \pm 8.87 tons) subsequent to the implementation of the CFSL. On the other hand, the Kruskal-Wallis test and ANOVA did not show any significant differences among the monthly means, when grouped per year, for both periods $\left(H_{(11.312)}=14.22128\right.$ and $\left.p=0.221\right)$ (Figure 4).

The distribution of monthly means of confiscations of the Arapaima sp. also revealed two different scenarios: i) in the period that precedes the CFSL, the highest numbers of confiscations occurred, which in turn showed high rates of fish confiscations during the rising water season, flood water, and receding water seasons (during August, the Arapaima sp. confiscations occurred more intensively), with a notable decrease in this activity during the drought season, and ii) in contrast, in the period after the implementation of the CFSL, there were lower confiscation rate values, which correlated with a decrease in rising water season, and flood seasons, with an apparent increase in the number of confiscations of Arapaima sp. during receding water and drought seasons, with special focus on October, when the highest number of illegal fishing confiscations for this species occurred (Figure 4).

This variations in the quantity of Arapaima sp. seizures could be an indicative of seasonal interactions between the fish stock and the aquatic environment, since the fish schools use the rising and flood water periods to reproduce in the floodplain areas (SOUSA et al., 2008). This is a preferred area for the pirarucu reproduction and serves as a nursery for offspring. The fisherman knows the behavior of fish shoals and the seasonality of the waters (SOUSA et al., 2017), which may have contributed to the success of clandestine fisheries and thus increased seizures of pirarucu prior to the implementation of CFSL.

Another possible scenario to explain the occurrence of higher seizure levels of pirarucu during the receding and drought periods could be a result of the effectiveness of the CFSL, since the beginning of the closed season occurs on November $15^{\text {th }}$, thus the fishermen raised their fishery effort in October in order to 
increase their incomes.

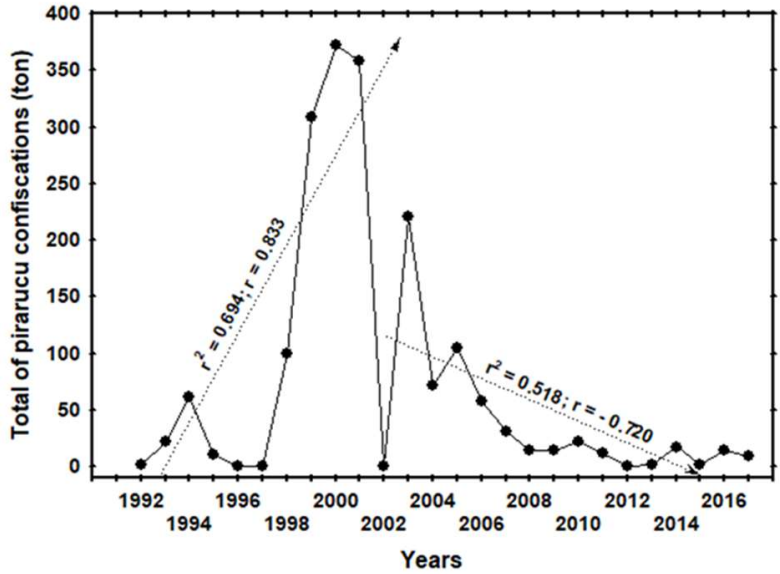

Figure 3: Analysis of total rates of confiscated Arapaima sp. (in metric tons), which occurred in the main tributaries of the Brazilian Amazon basin. The data correspond to an 11-year period (from 1992 to 2002) prior to the CFSL in 2002, and the following 15 years (from 2003 to 2017) after this law was implemented

(Decree $N^{\circ}$. 142/2002).

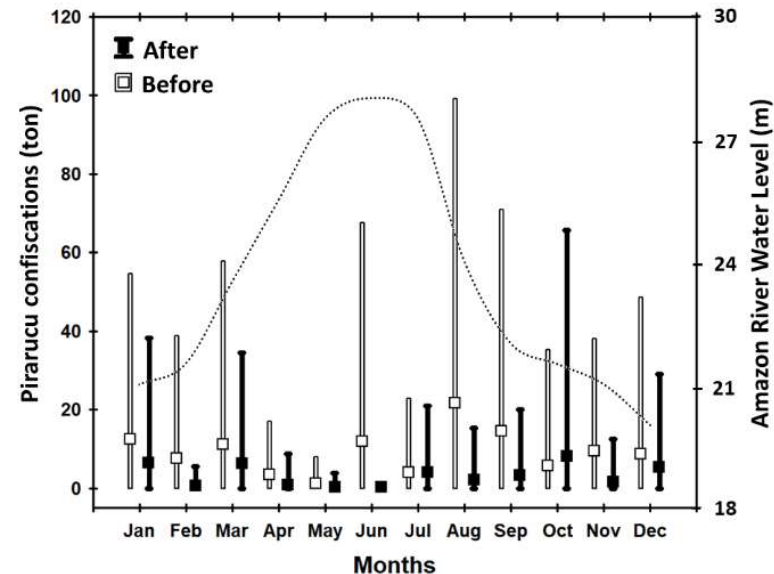

Figure 4: Monthly mean values of confiscations of Arapaima sp. which occurred in the period preceding the CFSL (from 1992 to 2002 - the CFSL was not implemented during this period) and after its implementation (from 2003 to 2017). The dotted line shows the variations in the Amazon River's water levels.

Over the last two decades, illegal fishing activities have been a threat to the survival of natural stocks of fish (DIAS et al., 2013), and there is a high rate of activity in the Amazon basin (CORRÊA et al., 2014; CAVOLE et al., 2015), since it is a rich region, with abundant aquatic biodiversity. Thus, this large aquatic environment contributes to the work of formal and informal fishermen (small-scale artisanal fisheries), who make up more than 50\% of the country's fish production (GASALLA et al., 2015), and invest their fishing efforts particularly in the fish with high commercial value, such as tambaqui and pirarucu. Fishing activities in the Amazon basin are carried out according to the variation in the river's seasonal water levels (GARCEZ et al., 2017). These variations occur in the periods from December to April (rising water season), May and June (high water or flood seasons), from July to September (receding water season) October and November (low water or drought season) as indicated by Bittencourt et al. (2007).

According to archeological records, the use of the pirarucu meat as a food source started with the Amerindian societies, and confirms the exploration of the species since a very long time ago. It also occurred in the Amazon in pre-colonial times, between the $16^{\text {th }}$ and $19^{\text {th }}$ centuries (MURRIETA, 2001; WWF, 2011). The local fishermen were responsible for fishing pirarucu and taking the fish to the "Royal Fishing Boats" in order to supply and feed the military and the employees of the Royal farm, ensuring the substitution of the Godus morhua, and thus starting the commercial exploitation of the pirarucu (WWF, 2011). However, in the 1950s, due to technological advances in fisheries, such as boats with engines that gradually made possible the expansion of commercial fishing, and consequently the fish stocks were brought to a level considered to be overexploited. This, in turn, at the end of the last century, unleashed the creation of preservation and conservation policies for native fishing resources, such as the pirarucu (Arapaima gigas), which was a popular item in the Amazonian fish markets (MURRIETA, 2001).

The formation of flood plains that exist in the Amazon are responsible for a huge variety of fish, and 
these areas particularly favor the establishment of pirarucu. However, the ease of access to these areas also increases its vulnerability to fisheries that act in this aquatic environment (MURRIETA, 2001). On this hydrological scale, the IBAMA agency aimed to protect the natural fish stock, by establishing the specific months for prohibition of fishing activities. These occur during the periods of rising water and flood seasons, a specific period where the water overflows the river banks, and enlarges the floodplain areas. Thus, this seasonal water pattern, difficulty in inspecting fisheries, as a consequence, make it easier for illegal fishermen to act (GASALLA et al., 2015; CAVOLE et al., 2015), thus, all these facts contribute to the depletion of all fish species, including those of Arapaima sp. (BESSA et al., 2010).

As an attempt to minimize the impacts of fisheries on the pirarucu stocks (OVIEDO et al., 2015), restrictive measures were created by the IBAMA, through the Decree $N^{\circ} 1534 / 89$ which determines the minimum size for Arapaima sp. catches (1,50 m in total length), followed by Decree $\mathrm{N}^{\circ}$ 480/91, which prohibited the fishing of the pirarucu specimens in the Brazilian Amazon from the period of December $1^{\text {st }}$ to May $31^{\text {st }}$. However, in 2001 this regulation was annulled and substituted by the IBAMA normative instruction $N^{\circ} 34 / 2001$, which regulates the prohibition of fishing of this fish species for the entire year. However, after the implementation of the decrees and the normative instruction of IBAMA, Arantes et al. (2010) carried out a study on the population density of pirarucu in the Sustainable Development Reserve (RDSM) of Mamirauá, in the state of Amazonas, which is a reserve that employs alternative practices to enable the sustainable development of Arapaima sp. fisheries in natural environments. The results of this study were promising, since they demonstrated that through the participatory management of fisheries (communities and government regulatory bodies - IBAMA) it is possible to recover over-exploited pirarucu stocks.

The data in the present study show that even with the efforts towards the preservation of the species in question, clandestine fishing of pirarucu is still underway. As a result, this continues to be a threat to the natural stocks of this fish. On the other hand, it was noticeable that from the year of 2003 onwards, there was a reduction in the amount of fish confiscated due to illegal fishing of Arapaima sp., and this may be attributed to the existence and positive effect of the CFSL.

Nevertheless, some actions should be taken into account in order to improve restrictive measures regarding fishing activities. One such aspect is the correct determination of the minimum size of Arapaima sp. that may be captured, as not all individuals of this species reach their sexual maturity within the length established by law $(1,50 \mathrm{~m})$. Records exist of individuals reaching maturity only after reaching 1,57 meters (ARANTES et al., 2010), which, if not corrected, can endanger populations in a certain region (QUEIROZ et al., 1999; ARANTES et al., 2010). However, the sexual maturity of this species is more relaxed after the fourth or fifth year of its life, when these individuals attain a length between 1,60 to 1,85 meters and a weight ranging from 40 to $45 \mathrm{~kg}$ (WWF, 2011).

Even with other restrictive actions, such as the Rondônia State Law $\mathrm{N}^{\circ} 1038$ of January $22^{\text {nd }}, 2002$, which determines a prohibition for the capture, transportation and commercialization of the Arapaima sp. except for subsistence fishing (meeting the regulations of the CFSL) and for certified fish farms, and was established in order to inhibit the capture of young pirarucu individuals, it is observed that, despite the 
importance of fishing in the Amazon region, this activity requires further regulations, criteria and parameters. In addition, any new policies need to be more consistent and appropriately comprise the specific needs required in this region, principally in a sustainable way (CORRÊA et al., 2014).

Due to increasing demand for fish which have brought stock shortages of the pirarucu in its natural habitat, it was necessary to create an efficient alternative for its preservation (e.g. fishing zoning areas) (DIAS et al., 2013; FREITAS et al., 2014). This has obtained positive results, through the utilization of management techniques which involved the unification of the resource users (riparian communities), inspection agencies (IBAMA and forest police) and environmental preservation (managed lakes) in a participative manner in this process. This resulted in a production of about 480 tons of Arapaima sp. for the year of 2016, of which all fish were caught in a legalized and rational manner (INSTITUTO MAMIRAUÁ, 2017).

Analyzing the total confiscations for Arapaima sp. in the Brazilian Amazon over the last 26 years, it is possible to notice an expressive peak in the numbers of confiscations, sub-sequenced with significant declines. However, of a total of 1,829 tons of confiscated pirarucu, $78.13 \%$ of these originated from the Solimões and Negro rivers, and most fisheries occurred in the municipality of Manaus and surrounding areas. This pattern near Manaus in the rate of confiscations for Arapaima sp. can be an indication of the human population growth in this municipality, which currently has 2.130 .264 inhabitants (IBGE, 2017), many of which arrived in this region looking for jobs due to the creation of Manaus Free Trade Zone (BESSA et al., 2010). This, as a result, has also influenced the increasing consumption and commercialization of Arapaima sp., among other fish species, and has characterized Manaus as the largest fishing port in the Amazonas State (BESSA et al., 2010). However, the other rivers (Purus, Japurá, Amazon, Uatumã, Madeira, Javari, Ipixuna, Jutaí, Nhamundá and Paraná Urariá) have also contributed $21.87 \%$ of the total of pirarucu confiscated in the study region.

Through data analysis, we obtained scenarios corresponding to the periods preceding the CFSL and subsequent to it. In the decade comprising the period from 1992 to 2002, before this law came into effect, there were high confiscation rates $(\approx 70 \%)$ of Arapaima sp. due high levels of clandestine fishing activities, and the highest rate in confiscations occurred in 2000 when a total of 360 tons of pirarucu were confiscated. On the other hand, in the following 15 years, from 2003 to 2017, there was a moderate reduction (51\%) in the numbers of these confiscation records, ranging from 60 tons in 2004 to 10 tons in 2017. This decline in the number of confiscations of Arapaima sp. can be attributed to two main factors. The first is that since the pirarucu was included on the red list with endangered species, the use of numbered tags was made compulsory for commercialization and transportation of this fish species. In this situation, it can be ensured that the pirarucu originated from fishery management schemes (e.g., managed lakes for development of pirarucu, and fish farming), making it more difficult for clandestine fishers to act (Normative Decree $\mathrm{N}^{\circ}$. 001/2005 - IBAMA). The failure to meet this requirement implies illegal fishing of this species, and the fishers can be subject to penalties under Law $\mathrm{N}^{\circ} 9.605 / 98$ and Decree $\mathrm{N}^{\circ} 3.179 / 99$. The second reason may be related to the lack of effective environmental inspectors, since the current staff are unable to control the vast and remote areas used by illegal fishing. 
When the results were compared to the periods established for the prohibition of fishing activity and the other months established for its liberation, it is also possible to see two different scenarios for the periods preceding and following the implementation of the CFSL. First, when the months defined for the fishing season to be closed (December to May) were compared with those periods of the open fishing season, in the decade before the implementation of the CFSL, these months showed the highest confiscation rates. On the other hand, the confiscation of pirarucu after the implementation of the CFSL showed a lower rate, though a high confiscation rate during the Closed fishing Season period (months) was noted. These results indicate that the total number of clandestinely fished Arapaima sp. suffered a significant decrease in after the implementation of the CFSL.

The organization and compliance in the execution of regulations prescribed by CFSL are important, but other aspects such as practices that follow proper management rules (CAVOLE et al., 2015), community agreements, establishment of quotas for the total fisheries catch (CASTELLO et al., 2013), minimum total length for target fish species in fishing activities (ARANTES et al., 2010), must also be in place in order to guarantee the preservation and sustainability of the Arapaima sp. stocks, as well as for other fish species.

The present study shows that the national aquaculture policies, when implemented in an incisive and restrictive way on the actions of violators of fishing laws, are efficient for restraining illegal fishing activities. However, fishery management policies need to consider in this process the insertion of strategies for awareness of riparian and non-riparian communities, as well as the need for maintenance and preservation of natural renewable resources (fish stock and their habitats). The policies must also take into account the need for and maintenance of social and economic sustainable development of communities. Policy practices used in the managing of Arapaima sp. stocks in the Amazon could be expanded to the other fishery stock areas in the Brazilian Amazon, with the aim of preserving, maintaining and conserving them for future generations.

\section{CONCLUSIONS}

The results indicate that the number of confiscations of illegally fished Arapaima sp. in the Brazilian Amazon decreased after the implementation of the Closed Fishing Season Law. This proves that its enforcement, combined with intensification of inspections, enabled the sustainability of the remaining pirarucu stocks, and demonstrated that this strategy can be used as a (positive) measure for preservation and sustainable management of the other fishery stocks in this region, as well.

\section{REFERENCES}

ARANTES, C. C.; CASTELLO, L.; STEWART, D. J.; CETRA, M.; QUEIROZ, H. L.. Population density, growth and reproduction of Arapaima in an Amazonian river-floodplain. Ecology of Freshwater Fish, v.19, p.455-465, 2010. DOI: https://doi.org/10.1111/j.1600-0633.2010.00431.x

ARANTES, C. C.; GARCEZ, D. S.; CASTELLO, L.. Densidades de pirarucu (Arapaima gigas, Teleostei, Osteoglossidae) em lagos das reservas de desenvolvimento sustentável
Mamirauá e Amanã, Amazonas, Brasil. Jornal Uakari, v.2, p.01-07, 2006. DOI:

http://dx.doi.org/10.31420/uakari.v2i1.13

BARD, J.; IMBIRIBA, E. P.. Piscicultura do pirarucu, Arapaimas gigas. Belém: EMBRAPA, 1986.

BESSA, J. D. O.; LIMA, A. C.. Manejo de pesca do pirarucu (Arapaima gigas) no Estado do Amazonas: erros, acertos e 
perspectivas futuras. In: SEMINÁRIO INTERNACIONAL DE CIÊNCIAS DO AMBIENTE E SUSTENTABILIDADE NA AMAZÔNIA, 1. Anais. Amazonas, 2010.

BITTENCOURT, M. M.; AMADIO, S. A.. Proposta para identificação rápida dos períodos hidrológicos em áreas de várzea do rio Solimões-Amazonas nas proximidades de Manaus. Acta Amazônica, v.37, p.03-06, 2007. DOI: https://doi.org/10.1590/S0044-59672007000200019

CASTELLO, L.; MCGRATH, D. G.; HESS, L. L.; COE, M. T. LEFEBVRE, P. A.; PETRY, P.; MACEDO, M. N.; RENÓ, V. F.; ARANTES, C. C.. The vulnerability of Amazon freshwater ecosystems. Conserv., v.6, p.217-22, 2013.

CAVOLE, L. M.; ARANTES, C. C.; CASTELLO, L.. How illegal are tropical small-scale fisheries? An estimate for Arapaima in the Amazon. Fisheries Research, v.168, p.01-05, 2015. DOI: https://doi.org/10.1016/j.fishres.2015.03.012

CORRÊA, M. A. A.; KAHN, J. R.; FREITAS, C. E. C.. Perverse incentives in fishery management: The case of the in the Brazilian Amazon.Ecological Economics, v.106, p.186-194, 2014. DOI: https://doi.org/10.1016/j.ecolecon.2014.07.023

DIAS, G. A. C.; BARBOZA, R. S. L.; JÚNIOR, B. F. D.; BRITO, D. M. C.; DIAS, T. C. A. C.. Diagnóstico da pesca ilegal no Estado do Amapá, Brasil. Planeta Amazônia: Revista Internacional de Direito Ambiental e Políticas Públicas, v.5, p.01-16, 2013.

DORIA, C. R. C.; ARAÚJO, T. R.; SOUZA, S. T. B.; VILARA, G. T.. Contribuição da etnoictiologia à análise da legislação pesqueira referente ao defeso de espécies de peixes de interesse comercial no oeste da Amazônia Brasileira, rio Guaporé, Rondônia, Brasil. Jornal Biotemas, v.21, p.01-14, 2008. DOI: https://doi.org/10.5007/21757925.2008v21n2p119

FREITAS, C. E. C.; SOUZA, F. K. S.; FLORENTINO, A. C.; HURD, L. E.. The importance of spatial scales to analysis of fish diversity in Amazonian floodplain lakes and implications for conservation.Ecology of Freshwater Fish, v.23, p.470-477, 2014. DOI: https://doi.org/10.1111/eff.12099

GARCEZ, R. C. S.; SOUZA, L. A.; FRUTUOSO, M. E.; FREITAS, C. E. C.. Seasonal dynamic of Amazonian small-scale fisheries is dictated by the hydrologic pulse. Boletim do Instituto de Pesca, São Paulo, v.43, n.2, p.207-221, 2017. DOI: http://doi.org/10.209501/1678-2305/2017v43n2p207

GÄRDENFORS, U. L. F.; STATTERSFIELD, A. J.. Red List of Threatened Species. Gland: IUCN, 1996.

GASALLA, M. A.; YKUTA, C.. 'Revelando a pesca de pequena escala’. São Paulo: Instituto Oceanógrafo, 2015.

IBGE. Instituto Brasileiro de Geografia e Estatística. Censo Demográfico. Brasília: IBGE, 2017.

INSTITUTO MAMIRAUÁ. Conservação na Amazônia. Manejo e Desenvolvimento. Manaus: Instituto Mamirauá, 2017.

ISAAC, V. J.; BATISTA, V.. Ecologia da Fauna Íctica. In: ISAAC, V. J.; BATISTA, V.. Peixes e pesca no Solimões-Amazonas: uma avaliação integrada. Brasília, 2012. p.201-246.

LIMA, L. G.; BATISTA, V. S.. Estudos etnoictiológicos sobre o pirarucu Arapaima gigas na Amazônia Central. Acta

Amazônica, v.42, p.337-344, 2012. DOI:

https://doi.org/10.1590/S0044-59672012000300005

LOPES, G. C. S.; FREITAS, C. E. C.. Avaliação da pesca comercial desembarcada em duas cidades localizadas no rio Solimões - Amazonas. Biota Amazônia, v.8, p.36-41, 2018. DOI: http://dx.doi.org/10.18561/21795746/biotaamazonia.v8n4p36-41

MATEUS, W. D.; BALDOINI, M.; ZACARIAS, J. F. E.; HIGUCHI, M. I. G.. Amazônia no Antropoceno: o manejo como relação entre humanos e fauna silvestre. Jornal Interações, v.19, p.01-16, 2017. DOI:

https://doi.org/10.20435/inter.v19i3.1667

MURRIETA, R. S. S. A.. Mística do pirarucu: pesca, ethos e paisagem em comunidades rurais de baixo Amazonas. Horizontes Antropológicos, v.7, p.01-18, 2001. DOI: https://doi.org/10.1590/S0104-71832001000200006

OVIEDO, A. F. P.; BURSZTYN, M.; DRUMMOND, J. A.. Agora sob nova administração: acordos de pesca nas várzeas da Amazônia brasileira. Revista Ambiente \& Sociedade, v.18, p.119-138, 2015.

PEDROZA FILHO, M. X.; MUÑOZ, A. E. P.; RODRIGUES, A. P. O.; REZENDE, F. P.; LIMA, A. F.; MATAVELI, M.. Panorama da cadeia produtiva do pirarucu. Confederação da Agricultura e Pecuária do Brasil, v.8, p.02-05, 2016.

QUEIROZ, H. L.; SARDINHA, A. D.. A preservação e o uso sustentado dos pirarucus (Arapaima gigas, Osteoglossidae) em Mamirauá. In: QUEIROZ, H. L.; SARDINHA, A. D.

'Estratégias para o manejo de recursos pesqueiros em Mamirauá'. Manaus: Sociedade Civil Mamirauá, 1999. p.01197.

RUFFINO, M. L.; ISAAC, V. J.. Dinâmica populacional do surubim-tigre, Pseudoplatystoma tigrinum (Valenciennes, 1840) no médio Amazonas (Siluriformes, Pimelodidae). Acta Amazonica, v.29, n.3, p.463-463, 1999. DOI: https://doi.org/10.1590/1809-1999293476

SANTOS, C. C. S.; FILHO, M. S. N.. O desenvolvimento regional através de práticas sustentáveis na Amazônia. Observatório de la Economia Latinoamericana, n.206, 2015.

SANTOS, G. M.; SANTOS, A. C. M.. Sustentabilidade da pesca na Amazônia. Estudos Avançados, v.19, p.01-18, 2005. DOI: https://doi.org/10.1590/S0103-40142005000200010

SOUSA, R. G. C.; FREITAS, C. E. C.. The influence of flood pulse on fish communities of floodplain canals in the Middle Solimões River, Brazil. Neotropical Ichthyology, v.6, p.01-07, 2008. DOI: https://doi.org/10.1590/S1679$\underline{62252008000200013}$

SOUSA, R. G. C.; SOUZA, L. A.; FRUTUOSO, M. E.; FREITAS, C. E. C.. Seasonal dynamic of Amazonian small-scale fisheries is dictated by the hydrologic pulse. Boletim do Instituto de Pesca, v.43, p.207-221, 2017. DOI: https://doi.org/10.20950/1678-2305.2017v43n2p207

VIANA, A. P.. Características físico químicas de pirarucu (Arapaima gigas) salgado e seco capturado em reservas extrativistas no Estado do Amazonas. In: SEMINÁRIO 
INTERNACIONAL DE CIÊNCIAS DO AMBIENTE E

SUSTENTABILIDADE NA AMAZÔNIA. Anais. Manaus, 2010.
WWF. World Wide Fund for Nature. Manejo do pirarucu: Sustentabilidade nos Lagos do Acre. Relatório Técnico. Projeto Alto Purus. Brasília: WWF, 2011.

A CBPC - Companhia Brasileira de Produção Científica (CNPJ: 11.221.422/0001-03) detém os direitos materiais desta publicação. Os direitos referem-se à publicação do trabalho em qualquer parte do mundo, incluindo os direitos às renovações, expansões e disseminações da contribuição, bem como outros direitos subsidiários. Todos os trabalhos publicados eletronicamente poderão posteriormente ser publicados em coletâneas impressas sob coordenação da Sustenere Publishing, da Companhia Brasileira de Produção Científica e seus parceiros autorizados. Os (as) autores (as) preservam os direitos autorais, mas não têm permissão para a publicação da contribuição em outro meio, impresso ou digital, em português ou em tradução. 